\title{
EVOLUTION OF TROPHIC SYSTEMS IN SQUAMATES
}

\author{
by \\ K.V. KARDONG ${ }^{1}$, T.L. KIENE ${ }^{1}$ and V. BELS ${ }^{2}$ \\ ( ${ }^{1}$ Department of Zoology, Washington State University, Pullman, WA 99164-4236, USA; \\ ${ }^{2}$ Institut Provincial d'Enseignement Superieur Agricole et Technique C.A.R.A.H., \\ rue Paul Pastur 11, B-7800 Ath, Belgium)
}

\section{ABSTRACT}

From lizards to snakes, the trophic system of squamates exhibits at least six major modifications correlated with different feeding strategies. Beginning in lizards, these include 1) shift from tongue to jaws as the primary means of prey capture, accompanied by specialization of the tongue for chemoreception, and 2) increasing skull kineticism. These features continue into snakes along with 3) unilateral jaw displacement during swallowing accompanied by 4) increasing skull kineticism, 5) development of the cervical vertebrae into a lever system for launching the strike, 6 ) addition of sensory modalities (thermoreception) in some snakes, and in advanced snakes, 7) shift from mechanical to chemical means of predation. Many fundamental features elaborated into the highly kinematic and jaw-based feeding system of snakes actually appear first within lizards. However, the highly kinetic skull of snakes represents not so much an extrapolation of lizard kinesis, as it does a rebuilding, even redesign, of the skull to achieve its high level of kinesis.

KEY WORDS: kinesis, lizard, snake, trophic system, character transformation.

\section{INTRODUCTION}

The trophic system of squamates includes the jaws and soft tissues immediately responsible for prey prehension, intraoral transport, and swallowing. Evolutionary modifications of the squamate trophic system have been quite extensive, leading to substantially different groups of living squamates, lizards and snakes. These changes occurred within a functionally integrated system, the jaw apparatus, and therefore raise issues about how such modifications might occur without disrupting current biological roles (FRAZZETTA, 1975). Our analysis of squamate trophic systems suggests that many of the evolutionary changes that were to collectively produce the highly derived, kinetic skulls and feeding systems of snakes, debuted first within lizards. As a guide to tracking these changes, we will begin by placing these modifications within a phylogenetic context. Then, we will analyze which character transformations passed directly to serpentes 
and which might be re-inventions or alternative solutions to mechanical problems of feeding.

\section{PHYLOGENY}

The close relationship of snakes and lizards has long been recognized but often complicated by convergences (e.g., limblessness) on the one hand, and great diversity within each group on the other. Amphisbaenians have been proposed as ancestors to snakes (RAGE, 1982). Although they may represent scleroglossan lizards (ESTES et al., 1988), it now seems unlikely that amphisbaenians are immediate ancestors to snakes as this would produce a number of character conflicts suggesting numerous reversals or convergences (RIEPPEL, 1988). Others have proposed that snakes and lizards originated from a common ancestor (HOFFSTETTER, 1962, 1968; RIEPPEL, 1983). However, squamates seem to be a monophyletic group whose sister group, among living species, is Sphenodon (ESTES et al., 1988; GAUTHIER et al., 1988). Specifically we adopt the classification proposed by SCHWENK $(1988,1993)$ because it is consistent with squamate monophyly; for snakes we adopt RAGE (1987) because it gives us sufficient resolution of relationships within serpent groups and generally is in keeping with other schemes (e.g., DESSAUER et al., 1987; RIEPPEL, 1988; CADLE, 1994), but as a convenience we retain Henophidia (sensu UNDERWOOD, 1967; RIEPPEL, 1977). The cladogram is presented in figure 1 .

\section{MODIFICATIONS}

Perhaps it could be argued that most squamate features serve trophic systems. Limblessness gives some lizards access to subterranean foods and some snakes a slender body to constrict prey. However, we intend to be more limited in our survey, restricting our analysis to major modifications in the squamate jaw apparatus as it is used during feeding and to specialized receptors that guide its use during prey capture. Within squamates, we recognize seven such major character transformations.

\section{Lingual to jaw prehension}

Within lizards, the shift from lingual to jaw prehension has been noted (SCHWENK, 1993). The tongue of iguanians participates in prey capture and in chemoreception. Its role in prey capture may be substantial (SMITH, 1984; SCHWENK \& THROCKMORTON, 1989; BELS, 1990; WAINWRIGHT et al., 1991; KRAKLAU, 1991) and the foretongue (anterior tongue tip) usually 


$$
\text { 戚 }
$$


bears specialized glandular epithelium that facilitates adhesion of tongue to prey during prey capture (BELS \& BALTHUS, 1987; SCHWENK, 1988, 1993). However, within scleroglossan lizards generally, and anguimorphs in particular, the tongue becomes largely dedicated to chemoreception with accompanying specialized anatomical modifications (MCDOWELL, 1972). The tongue's role in feeding is reduced, its glandular epithelium on the foretongue diminished, and the jaws assume the major role in prey capture (SMith, 1982, 1986; SCHWENK, 1988; Bels \& GoOsSE, 1990; GoOSSE \& BELS, 1992).

The squamate tongue may participate in drinking (KARDONG \& HAVERLY, 1994), but it becomes anatomically specialized (MCDOWELL, 1972) for chemoreception, used for frequent sampling and delivery of chemicals to the vomeronasal organ (HALPERN, 1988; KUBIE \& HALPERN, 1978, 1979; HALPERN \& KUBIE, 1983; COOPER, 1990). In snakes, chemoreception by the tongue is important in prey trailing before (HALPERN, 1988; KUBIE \& HALPERN, 1978, 1979; HALPERN \& KUBIE, 1983) and after strikes (KARDONG, 1992). But such roles and specialized designs are already present within anguimorph lizards (COOPER, 1990).

\section{Skull kineticism}

Cranial kinesis occurs within squamates, but its distribution among taxa is incompletely known. In part this is due to the incomplete examination of a wide range of species. Only a few have been studied, and occasionally the criteria for kinesis vary among workers. Strictly speaking, cranial kinesis might apply only to skulls in which there is a transcranial joint, producing metakinesis (back of skull), mesokinesis (parietal-frontal), or prokinesis (frontal-snout) singlely or in combinations (FRAZZETTA, 1962). However, the term cranial kinesis has also been used to describe skulls with extensive independent movements of elements relative to the neurocranium with or without the aid of a transcranial joint. Some distinctive aspects of cranial kinesis may occur only during prey capture, but often studies are of the later intraoral transport phase and therefore intracranial movements have gone unnoticed (BORSUK-BIALYNICKA, 1985). Further, experimental methods used to detect cranial kinesis have varied among research efforts (see appendix). Certainly fresh skull bones bend under hand manipulation, but how much of this flexion or rotation occurs under natural feeding conditions is less well examined. To date, only a few studies have attempted to empirically measure kinetic events directly in lizard skulls (THROCKOMORTON \& Clarke, 1981; SMith \& HYlander, 1985; FrazzetTA, 1983; Condon, 1987), sometimes producing conflicting results. For all these reasons, it is difficult to track homologous kinetic characters within squamates based on literature reports. 
In lizards, where an active mesokinetic joint is present, the palate also enjoys some degree of accompanying sliding and/or rotation about intrinsic joints. During protraction/retraction displacements, the posterior part of the paired palate undergoes displacements in a horizontal plane, sliding on its articulation with the basipterygoid process. The anterior palate rotates about a transverse axis passing through the pterygoid-palatine and ectopterygoidmaxilla joints within the palate. The anterior palate accompanies the snout as it rises and depresses. Such kinetic mechanisms in lizards may aid prey capture by improving the synchronization of upper and lower jaw closure, and by more favorably orienting teeth to prey surface (FRAZZETTA, 1962, 1986; RIEPPEL, 1979).

Generally then, an active mesokinetic joint within a lizard skull suggests the presence of cranial kinesis that serves, at least, in prey capture. Outside of Chamaeleontids, such mesokinetic joints have been reported in all major lizard families including the legless Pygopodidae (see appendix). Streptostyly is reported in all lizard families (except Lacertidae), but prokinesis is unknown in lizards (see appendix), and metakinesis and metakinesis are unknown in snakes.

\section{Bilateral to unilateral feeding}

Lizards, like most tetrapods (BRAMBLE \& WAKE, 1985), swallow using bilateral displacements of jaws, in which both mandibular rami open and close synchronously. However, in snakes, jaw displacements during swallowing are distinctly unilateral (sensu GANS, 1961). The palatomaxillary and mandibular arches on a side are not firmly joined to their partners of the opposite side. This allows each half of the paired arch to move independently, constrained primarily by immediate attachments (muscular, bony, ligamentous) to the adjacent braincase and internally between bony members of each arch. During most parts of intraoral transport, the arches of one side relax their pressure against the prey, protract, and are carried by rotation of the entire braincase over the surface of the prey; then they re-engage the prey further along its body. Next, the arches of the opposite side take their turn to advance through the same motions. As alternating left and right sides move in turn, the reciprocating character to unilateral prey transport is established (ALBRIGHT \& NELSON, 1959; BOLTT \& EWER, 1964; KARDONG, 1977, 1986; Cundall, 1983; Cundall \& GANS, 1979).

Although absent in lizards, evidence of unilateral jaw displacements have been noted in Henophidia, primitive alethinophidian snakes (CUNDALL, 1995). The taxon Henophidia (sensu UNDERWOOd, 1967) has been reexamined (e.g., RiEPPEL, 1988; CADLE, 1995; Cundall et al., 1993) and although their relationship may need to be better resolved, member taxa 
such as Anomochilidae, Cylindrophiidae, Uropeltidae, and Aniliidae certainly seem to be among the most primitive living alethinophidians. So far, studies of the Scolecophidia have not confirmed (or refuted) unequivocally the presence of unilateral feeding.

Along with a unilateral mode of jaw displacements, prokinesis makes its debut in snakes. It seems to be related to 'snout shifting' (CUNDALL, 1995) and other loosenings of the ophidian skull (CUNDALL \& SHARDO, 1995) that prevent the snout from interfering with the forward translation of the palatomaxillary arch. Connections of the snout with the braincase which occur through the nasal-frontal joint in many primitive snakes, switch to a ventral point of articulation early in ophidian evolution (RIEPPEL, 1988).

\section{High degree kineticism}

As has been recognized (GANS, 1961), the snake skull is highly kinetic. But, down growth of several roofing bones, especially the parietals, produce a snake braincase that is very rigid. Active metakinetic and mesokinetic joints are eliminated completely. This kineticism in snakes is achieved, compared to lizards, by the strategic change of moveable skull joints from mostly synovial in lizards to mostly ligamentous syndesmotic joints in snakes and by further liberations of the palate (RIEPPEL, 1980). The quadrate suspension from the braincase, synovial in lizards, is ligamentous in most snakes (RIEPPEL, 1980). In some specialized snake species, these ligaments may produce a firm coupling. But, such ligamentous connections may also be employed to permit great rotation or displacement (e.g., KARDONG, 1977; YOUNG, 1988).

Further, in lizards, major joints linking the palate to the braincase are synovial. In snakes, these joints may be lost or replaced by ligaments (RIEPPEL, 1980). For example, the joint between the medial, distal end of the quadrate and the posterior pterygoid, synovial in many lizards (RIEPPEL, 1978), ligamentous in snakes, and in some Caenophidia may permit relatively considerable independent excursion of both bones (KARDONG, 1977).

Finally, firm, syndesmotic joints in lizards, may become highly movable, permitting considerably relative rotation of articulated bony units. Or, joined bones may become completely detached, and enjoy full independent motion. For example, the maxilla and premaxilla are tightly coupled through a syndesmotic joint in lizards, but in alethiophidia these bones no longer make contact with each other. The prokinetic joint (naso-frontal) of snakes represents the appearance of relative motion between the nasal unit and braincase, although it is not significant until Henophidia (RIEPPEL, 1978). 


\section{Cervical strike (lunge to strike)}

When capturing food, lizards walk or dash toward the quarry, and may finish the attack by forward advance of the body (lunge, delivery, FRAZZETTA, 1983). This may include arching of the neck in a dorsoventral plane (SMITH, 1984). In snakes, the jaws are accelerated toward the prey by use of lateral bends in the cervical and thoracic regions. Body acceleration is based on two patterns of body displacement, one in which acute sections of the body straighten, the other in which body segments flow around postural curves similar to movements seen during locomotion. However, even such a laterally based strike is evident in some lizards. During swallowing, varanid lizards may develop slow, lateral undulations within the cervical region which sweep posteriorly and may aid in passage of the prey from oropharyngeal cavity into the esophagus. Occasionally, varanid lizards may develop shallow lateral bends in their necks when approaching prey (personal observation), and during prehension, varanid lizards may also form shallow, lateral curves in the cervical region. However, these motor patterns or postures are not the basis for lunging the lizard forward during prey capture. Only in snakes is the axial column and musculature specialized to form lateral body coils from which to accelerate the jaws toward prey during prehension.

\section{Sensory modalities}

The most discrete infrared receptors are found in two groups of snakes, the Henophidia (pythons and boas) and the pit vipers (Viperidae). In both cases, the sensory receptor is a free nerve ending located in the skin. As the skin absorbs infrared radiation it is warmed; this excites the associated free nerve endings, which transmit this information to the optic tectum of the midbrain.

The oral mucosa of rattlesnakes includes a diffuse collection of infrared receptors (CHISZAR et al., 1986; DICKMAN et al., 1987). However, these are innervated independently of the trigeminal nerves serving the facial pits. Although these oral infrared receptors have been suggested to play a role during the strike when the mouth is open (CHISZAR et al., 1986), there is yet no evidence that rattlesnakes change trajectory of their head during the strike (KARDONG \& BELS, 1998). As recognized for some time (BULLOCK \& COWLES, 1952), the facial pit of crotaline snakes is predominant in affecting predatory behavior. In crotaline snakes, the infrared receptors reside within a thin membrane suspended across the sunken facial pit. The receptors are innervated by branches of the ophthalmic nerve and by branches of the maxillary nerve (superficial and deep). Each terminal nerve receptor is connected to a single peripheral nerve fiber (MOLENAAR, 1992). 
Although heat-sensitive receptors probably occur generally within squamates, only in boid and crotaline snakes are they associated with specialized morphological structures, the facial pits.

\section{Mechanical to chemical predation}

Except for the helodermatids, lizards do not have toxic oral secretions produced in exocrine glands and delivered by specialized teeth. How these toxins serve helodermatids is not known, but the presence of toxins seems to be a specialized feature of only this lizard group. Strong jaws are used to mechanically break open eggs or hold prey (BOGERT \& DEL CAMPO, 1956). But the helodermatid venom does not seem to be used to envenomate prey to quickly kill it and make the prey more easily controlled.

Venom secretion within snakes appeared late, among derived groups (GREENE, 1994), and produced several highly diversified groups of Caenophidia. In those colubrid snakes that use no venom, subduing prey occurs by constriction (GREENE \& BURGHARDT, 1978) or by overpowering use of the jaws alone. Swallowing of the dispatched prey may proceed directly from the position of the jaws, or the prey may be released and the snake searches for a new point on the prey to begin swallowing. In venomous snakes, the predatory strategy has changed from one based upon mechanical to chemical means (KARDONG \& LAVÍN-MURCIO, 1993). Chemical predation is characterized by delivery of toxins which kill the struggling prey, giving the snake control and allowing for more deliberate swallowing. Chemical predation allows further specialization of predatory behavior wherein the prey might be released after envenomation, thereby reducing risk to the snake of retaliation from a prey held in the jaws. Chemical predation is also used to speed digestion (THOMAS \& POUGH, 1979).

\section{DISCUSSION}

\section{Character transformations}

Kinetic character states are particularly difficult to evaluate in the skull because of the uncertainty of their identification. Mixed methods (see appendix) produce inconsistent results among research reports. And not all reports of kinesis have been verified within a normal behavioral context. Many claims of cranial kinesis are inferential from the anatomy or based only on hand-manipulated wet skulls. Unfortunately, vigorous hand-manipulation can force flexions in bones where none can be produced naturally by the lizard itself. Although useful to a point, such methods do not confirm 
whether the proposed kinetic displacements are actually used by the squamate during normal activity. Further cranial kinesis, even if present, might occur during predatory behavior (prehension-swallowing) or conceivably even during social displays. Such methods of inference and manipulation alone do not place kinesis with a normal behavioral context. These indirect methods produce uncertain character coding and make it difficult to evaluate cranial kinesis within squamates on a fine scale. However, some general observations of character transformation can be noted.

In Sphenodon, the tongue may be used to capture small prey (GORNIAK et al., 1982). Although its use may be complex (BELS \& KARDONG, personal obs.), the presence of such a feature in the sister group suggests it is a primitive feature within squamates. The mandible undergoes propalineal sliding, but any other form of skull kineticism is unknown in Sphenodon (GORNIAK et al., 1982). As mentioned above, differences in definition and experimental methods require that reports of kineticism in lizards be taken cautiously. However, mesokinesis has been reported in species in almost all families of lizards. If this proves to be correct, then mesokinesis likely arose early within lizards.

Several character transformations appeared in snakes. In snakes, unilateral feeding becomes the characteristic mode of swallowing prey. The use of a strike to quickly place jaws in a position to grasp prey replaces the lunge of lizards. Thermoreception, based on specialized receptor pits, appears within boidae (Henophidia) and within crotalines (Viperidae). The use of oral venoms to quickly kill prey appears first in advanced snakes. Oral toxins in helodermatid lizards probably do not serve similar functions. The absence of any venomous squamates between helodermatids and caenophida suggests that the lizard venom system is at most a convergent feature.

\section{Snake features appearing first in lizards}

Jaw based prehension and the specialization of the tongue for chemoreception characterize snakes, but these features occur first within lizards. Similarly, a kinetic skull which includes anterior/posterior translation of the palate also appears first within lizards although it becomes much more elaborated in snakes.

\section{Snake specializations}

The kinetic skulls found within lizards and snakes share a moveable palate. Dorsoventral flexion within the palate occurs about a transverse axis passing through the pterygo-palatine and ectopterygo-maxillary joints, as in lizards. But outside this, the basis for the kineticism is quite different. In snakes, a solid, akinetic braincase replaces the kinetic lizard braincase based upon 
metakinetic and mesokinetic joints. Joints that tend to be synovial in lizards are syndesmotic, and loose in snakes, permitting considerable rotation of the quadrate and of the palatomaxillary arch. A prokinetic joint, absent in lizards, is present in snakes. In short, the skull of snakes is based on a considerably different design that introduces this high degree of kineticism. Perhaps as reversal during a burrowing ancestry, snake visual systems have been rebuilt to serve above ground activity (WALLS, 1942; BELLAIRS \& UNDERWOOD, 1951). The skull too of snakes seems to be a rebuilt trophic system serving to catch and swallow large prey through redeveloped skull kineticism.

\section{REFERENCES}

ALBRIGHT, R.G. \& E.M. NELSON, 1959. Cranial kinetics of the generalized colubrid snake Elaphe obsoleta quadrivittata. I. Descriptive morphology. II. Functional morphology. J. Morph. 105: 193-240, 241-292.

BAUER, A., 1985. Notes on the taxonomy, morphology, and behavior of Rhacodactylus chahoua (Bavay) (Reptilia: Gekkonidae). Bonn. Zool. Beitr. 36: 81-94.

BELL, D.A., 1990. Kinematics of prey capture in the chameleon. Zool. Jb. Physiol. 94: $247-$ 260.

BELLAIRS, A. D'A, 1950. Observations on the cranial anatomy of Annelia, and a comparison with that of other burrowing lizards. Proc. Zool. Soc. Lond. 119: 887-904.

Bellairs, A. D'A. \& G. UNDERWOOD, 1951. The origin of snakes. Biol. Rev. 26: 193-237.

BELS, V.L. \& I. BALTUS, 1987. First analysis of the feeding sequence of Chameleo dilepis. Proc. Fourth Ord. Gen. Meeting S.E.H. Nijmegen: 67-70.

BELS, V.L., M. CHARDON \& K.V. KARDONG, 1994. Biomechanics of the hyolingual system in Squamata. In: V. BELS, M. ChaRdon, P. VANDERWALle (Eds): Advances in Comparative and Environmental Physiology, Vol. 18: 197-240.

BELS, V.L. \& K.V. KARDONG, 1998. Evolution of squamate prey capture behavior: lingual and kinematic jaw systems (in prep.)

BELS, V.L. \& V. GOOSSE, 1990. Comparative kinematic analysis of prey capture in Anolis carolinensis (Iguania) and Lacerta viridis (Scleroglossa). J. Exp. Zool. 255: 120-124.

BELS, V.L., V. GoOSSE \& K.V. KARDONG, 1993. Kinematic analysis of drinking by the lacertid lizard, Lacerta viridis (Squamates, Scleroglossa). J. Zool. 229: 659-682.

BogerT, C. \& R. DEL CAMPO, 1956. The gila monster and its allies. Bull. Amer. Mus. Nat. Hist. 109: 1-238.

BOLTT, R.E. \& R.F. EWER, 1964. The functional anatomy of the head of the puff adder, Bitis arietans. J. Morph. 114: 83-103.

BORSUK-BIALYNICKA, M., 1985. Comments on the kinetics of the lizard skull. Fortschritte Zool. 30: 135-137.

BRAMBLE, D.M. \& D.B. WAKE, 1985. Feeding mechanisms of lower tetrapods. In: M. HILDEBRAND, D.M. BRAMBLE, K.F. LIEM \& D.B. WAKE (Eds): Functional Vertebrate Morphology: 230-261. Harvard University Press, Cambridge.

BROCK, G.T., 1938. The skull of the chamaeleon Lophosaura ventralis (Gray); some developmental stages. Proc. Zool. Soc. Lond. 110: 219-241.

BROCK, G.T., 1941. The skull of Acontias melagris, with a study of the affinities between lizards and snakes. J. Linn. Soc. (Zool.) 41: 71-88.

BULlOCK, T.H. \& R.B. COWLES, 1952. Physiology of an infrared receptor: the facial pit of pit vipers. Science 115: 541-543. 
BURGHARDT, G.M., 1980. Behavioral and stimulus correlates of vomeronasal functioning in reptiles: Feeding, grouping, and tongue use. In: D. MÜLLER-SCHWARZE \& R.M. SILVERSTEIN (Eds): Chemical Signals: 275-301. Plenum Press, New York.

CADLE, J.E., 1994. The colubrid radiation in Africa (Serpentes: Colubridae): phylogenetic relationships and evolutionary patterns based on immunological data. Zool. J. Linn. Soc. 110: $103-140$.

ChISZAR, D., J.D. DickMAN \& J.S. COLTON, 1986. Sensitivity to thermal stimulation in prairie rattlesnakes (Crotalus viridis) after bilateral anesthetization of facial pits. Behav. Neural. Biol. 45: 143-149.

CONDON, K., 1987. A kinematic analysis of mesokinesis in the Nile monitor (Varanus niloticus). J. Exp. Biol. 47: 73-87.

COOPER, W.E., JR., 1990. Prey odour discrimination by lizards and snakes. In: V.D.W. MACDONALD, D. MÜLLER-SCHWARZE \& S.E. NATYNCZUK (Eds): Chemical signals in vertebrates: 533-538. Oxford University Press, Oxford, England.

CUNDALL, D., 1983. Activity of head muscles during feeding by snakes: a comparative study. Amer. Zool. 23: 383-396.

Cundall, D., 1987. Functional morphology. In: R.A. SEIGEL, J.T. Collins \& S.S. NovaK (Eds): Snakes-ecology and evolutionary biology: 106-142. Macmillan, New York.

CUNDALL, D., 1995. Feeding behaviour in Cylindrophis and its bearing on the evolution of alethinophidian snakes. J. Zool. (Lond). 237: 353-376.

Cundall, D. \& C. GANS, 1979. Feeding in water snakes: an electromyographic study. J. Exp. Zool. 209: 189-208.

CUNDALl, D. \& J. SHARDO, 1995. Rhinokinetic snout of thamnophiine snakes. J. Morph. 225: $31-50$.

Cundall, D., V. Wallach \& D.A. Rossman, 1993. The systematic relationships of the snake genus Anomochilus. Zool. J. Linn. Soc. 109: 235-273.

DELHEUSY, V. \& V.L. BELS, 1992. Kinematics of feeding behaviour in Oplurus cuvieri (Reptilia: Iguanidae). J. Exp. Biol. 170: 155-186.

Dessauer, H.C., J. CADLE \& R. LAWSON, 1987. Patterns of snake evolution suggested by their proteins. Fieldiana (Zool.) (N.S.) 34: 1-34.

DEVREE, F. \& C. GANS, 1987a. Intracranial movements in Gekko gecko (Reptilia: Sauria). Acta Anat. 130: 25 (Abstr.).

DeVreE, F. \& C. Gans, 1987b. Kinetic movements in the skull of adult Trachydosaurus rugosus. Anat. Hist. Embry. 16: 206-209.

Dickman, J.D., J.S. Coulton, D. ChiszaR \& C.A. ColTon, 1987. Trigeminal responses to thermal stimulation of the oral cavity in rattlesnakes (Crotalus viridis) before and after bilateral anesthetization of the facial pit organs. Brain Res. 400: 365-370.

ESTES, R., K. DE QUEIROZ \& J. GAUTHIER, 1988. Phylogenetic relationships within Squamata. In: R. ESTES \& G. PREGILL (Eds): Phylogenetic relationships of lizard families: 119-281. Stanford University Press, Stanford, California.

FrazZETTA, T.H., 1962. A functional consideration of cranial kinesis in lizards. J. Morph. 111: $287-320$.

FraZZETTA, T.H., 1966. Studies on the morphology and function of the skull in the Boidea (Serpentes). Part II. Morphology and function of the jaw apparatus in Python sebae and Python molurus. J. Morph. 118: 217-296.

FrAzZETTA, T.H., 1975. Complex adaptations in evolving populations. Sinauer Assoc. Inc., Massachusetts.

FRAZZETTA, T.H., 1983. Adaptation and function of cranial kinesis in reptiles: A time-motion analysis of feeding in alligator lizards. In: A.G.J. RHODIN \& K. MIYATA (Eds): Advances in Herpetology and Evolutionary Biology: 222-244. Harvard University Press, Cambridge, Massachusetts. 
FRAZZETTA, T.H., 1986. The origin of amphikinesis in lizards: A problem in functional morphology and the evolution of adaptive systems. In: M.K. HECHT, B. WALLACE \& G.T. PRANCE (Eds): Evolutionary Biology 20: 419-461. Plenum Press, New York.

Gans, C., 1961. The feeding mechanism of snakes and its possible evolution. Amer. Zool. 1: 217-227.

GAUTHIER, J., R. ESTES \& K. DE QUEIROZ, 1988. A phylogenetic analysis of Lepidosauromorpha. In: R. ESTES \& G. PREGILL (Eds): Phylogenetic relationships of lizard families: 15-98. Stanford University Press, Stanford, California.

GorniaK, G.C., H.I. Rosenberg \& C. GANS, 1982. Mastication in the tautara, Sphenodon punctatus (Reptilia: Rhynchocephalia): Structure and activity of the motor system. J. Morph. 171: 321-353.

GoossE, V. \& V.L. BELS, 1992. Kinematic and functional analysis of feeding behaviour in Lacerta viridis (Reptilia: Lacertidae). Zool. Jb. Anat. 122: 187-202.

GREENE, H.W., 1983. Dietary correlates of the origin and radiation of snakes. Amer. Zool. 23: $431-441$.

GREENE, H.W., 1994. Homology and behavioral repertoires. In: B.K. HALL (Ed.): Homology: The Hierarchical Basis of comparative Biology: 369-391. Academic Press, San Diego.

GREENE, H.W. \& G.M. BURGHARDT, 1978. Behavior and phylogeny: constriction in ancient and modern snakes. Science 200: 74-77.

HALPERN, M., 1988. Vomeronasal system functions: Role in mediating the reinforcing properties of chemical stimuli. In: W.K. SCHWERDTFEGER \& W.J.A.J SMEETS (Eds): The Forebrain of Reptiles: 142-150. Int. Symp. Recent Advances in Understanding the Structure and Function of the Forebrain in Reptiles, Karger, Basel, Frankfurt.

HALPERN, M. \& J.L. KUBIE, 1983. Snake tongue flicking behavior: Clues to vomeronasal system function. In: D. MÜLlER-SCHWARZE \& R.M. SilverSTEIN (Eds): Chemical Signals in Vertebrates, Vol. 3: 45-72. Plenum Press, New York.

HOFFSTETTER, R., 1962. Revue des récentes acquisitions concernant l'histoire et la systématique des squamates. Coll. Intern. CNRS 104: 243-278.

HOFFSTETTER, R., 1968. Review of "A contribution to the classification of snakes" by G. Underwood. Copeia 1968: 201-213.

IORDANSKY, N., 1966. Cranial kinesis in lizards: Contributions to the problem of the adaptive significance of skull kinesis in lizards. J. Morph. 111: 287-320. Translated by Dr. Leon Kelso. Smithsonian Herpetological Information Services, Washington D.C., 1968.

IORDANSKY, N., 1990. Evolution of cranial kinesis in lower tetrapods. Neth. J. Zool. 40: 32-54.

KARDONG, K.V., 1974. Kinesis of the jaw apparatus during the strike in the cottonmouth snake, Agkistrodon piscivorus. Forma et functio 7: 327-354.

KARDONG, K.V., 1977. Kinesis of the jaw apparatus during swallowing in the cottonmouth snake, Agkistrodon piscivorus. Copeia 1977: 338-354.

KARDONG, K.V., 1986. Kinematics of swallowing in the yellow rat snake, Elaphe obsoleta quadrivittata. A reappraisal. Jpn. J. Herp. 11: 96-109.

KARDONG, K.V., 1992. Proximate factors affecting guidance of the rattlesnake strike. Zool. Jb. Anat. 122: 233-244.

KARDONG, K.V. \& V.L. BELS, 1998. Rattlesnake strike behaviour: Kinematics. (Under review).

KARDONG, K.V. \& J.E. HAVERLY, 1993. Drinking by the common boa, Boa constrictor. Copeia 1993: 808-818.

KARDONG, K.V. \& P.A. LAVÍN-MURCIO, 1993. Venom delivery of snakes as high-pressure and low-pressure systems. Copeia 1993: 644-650.

KRAKLAU, D.M., 1991. Kinematics of prey capture and chewing in the lizard Agama agama (Squamata: Agamidae). J. Morph. 210: 195-212. 
KREBS, U., 1979. Der dumeril-waran (Varanus dumerii) ein spezialisierter Krabbenfresser? (Reptilia: Sauria: Varanidae). Salamandra 15: 146-157.

KUBIE, J.L. \& M. HALPERN, 1978. Garter snake trailing behavior: Effects of varying preyextract concentration and mode of prey-extract presentation. J. Comp. Physiol. Psychol. 92: $362-373$.

KUBIE, J.L. \& M. HALPERN, 1979. Chemical senses involved in karter snake prey trailing. J. Comp. Physiol. Psychol. 93: 648-667.

LAUDER, G.V. \& T. PRENDERGast, 1992. Kinematics of aquatic prey capture in the snapping turtle Chelydra serpentina. J. Exp. Biol. 164: 55-78.

MCDOwELL, S.B., 1972. The evolution of the tongue of snakes, and its bearing on snake origins. In: T. DOBZHANSKY, M.K. HECHT \& W.C. STEERE (Eds): Evolutionary Biology 6: 191-273. Plenum Press, New York.

MOLENAAR, G.J., 1992. Anatomy and physiology of infrared sensitivity of snakes. In: C. GANS \& P.S. UlinSKI (Eds): Biology of the Reptilia, Vol. 17C: 367-433. Alan R. Liss, Inc., New York.

PATChELl F.C. \& R. SHINE, 1986. Feeding mechanism in Pygopodid lizards: How can Lialis swallow such large prey? J. Herp. 20: 59-64.

RAGE, J-C., 1982. La phylogénie des Lépidosauriens (Reptilia): Une approche cladistique. C. R. Acad. Sci. Paris 294: 563-566.

RAGE, J-C. 1987. Fossil history. In: R.A. SeIGEl, J.T. Collins \& S.S. NovaK (Eds): Snakes: Ecology and Evolutionary Biology: 51-76. McMillan Publ. Co., New York.

REILLY, S.M. \& G.V. LAUDER, 1990. The evolution of tetrapod feeding behavior: kinematic homologies in prey transport. Evolution 44: 1542-1557.

RIEPPEL, O., 1977. Studies on the skull of Henophidia (Reptilia: Serpentes). J. Zool. Lond. 181: $145-173$.

RIEPPEL, O., 1978. The evolution of the naso-frontal joint in snakes and its bearing on snake origins. Z. Zool. Syst. Evolutionsforsch. 16: 14-27.

RIEPPEL, O., 1979. A functional interpretation of the varanid dentition (Reptilia, Lacertilia, Varanidae). Gegenbaurs Morph. Jahrb. 125: 797-817.

RIEPPEL, O., 1980. The evolution of the ophidian feeding system. Zool. Jb. Anat. 103: 551-564.

RIEPPEL, O., 1983. A comparison of the skull of Lanthanotus borneensis (Reptilia: Varanoidea) with the skull of primitive snakes. Z. Zool. syst. Evolutionsforsch. 21: 142-153.

RIEPPEL, O., 1988. A review of the origin of snakes. In: M.K. HECHT, B. WALlaCE \& G.T. PranCE (Eds): Evolutionary Biology 22: 37-130. Plenum Publ., New York.

SCHWENK, K., 1986. Morphology of the tongue in the tuatara, Sphenodon punctatus (Reptilia: Lepidosauria), with comments on function and phylogeny. J. Morph. 188: 129-156.

SCHWENK, K., 1988. Comparative morphology of the Lepidosaur tongue and its relevance to Squamate phylogeny. In: R. ESTES \& G. PREGILL (Eds): Phylogenetic Relationships of the Lizard Families: 569-598. Stanford University Press, Stanford, California.

SCHWENK, K., 1993. The evolution of chemoreception in squamate reptiles: a phylogenetic approach. Brain Behav. Evol. 41: 124-137.

SCHWENK, K. \& D.A. BELL, 1988. A cryptic intermediate in the evolution of chameleon tongue projection. Experientia 44: 697-700.

SCHWENK, K. \& G.S. THROCKMORTON, 1989. Functional and evolutionary morphology of lingual feeding in squamate reptiles: phylogenetics and kinematics. J. Zool. (Lond) 219: 153-175.

SMITH, K.K., 1978. Electromyographic and cineradiographic studies of feeding in lizards. Am. Zool. 18: 623.

SMITH, K.K., 1980. Mechanical significance of streptostyly in lizards. Nature 283: 778-779. 
SMITH, K.K., 1982. An electromyographic study of the function of jaw adductor muscles in Varanus exanthematicus. J. Morph. 173: 137-158.

SMITH, K.K., 1984. The use of the tongue and hyoid apparatus during feeding in lizards (Ctenosaura similis and Tupinambis nigropunctatus). J. Zool. (Lond) 202: 115-143.

SMITH, K.K., 1986. Morphology and function of the tongue and hyoid apparatus in Varanus (Varanidae, Lacertilia). J. Morph. 187: 261-287.

SMITH, K.K., 1988. Form and function of the tongue in Agamid lizards with comments on its phylogenetic significance. J. Morph. 196: 157-171.

SMITH, K.K., 1992. The evolution of the mammalian pharynx. Zool. J. Linn. Soc. 104: 313-349.

SMITH, K.K \& W.L. HYLANDER, 1985. Strain gauge measurements of mesokinetic movement in the lizard Varanus exanthematicus. J. Exp. Biol. 114: 53-70.

So, K.-K.J., P.C. WAINWRIGHT \& A.F. BENNETT, 1992. Kinematics of prey processing in Chamaeleo jacksonii: conservation of function with morphological specialization. J. Zool. (Lond) 226: 47-64.

Thomas, R. \& F.H. POUGH, 1979. The effect of rattlesnake venom on digestion of prey. Toxicon 17: 221-228.

THROCKMORTION, G.S., 1976. Oral food processing in two herbivorous lizards, Iguana iguana (Iguanidae) and Uromastix aegyptius (Agamidae). J. Morph. 148: 363-390.

THROCKMORTON, G.S. \& L.K. CLARKE, 1981. Intracranial joint movements in the agamid lizard Amphibolurus barbatus. J. Exp. Zool. 216: 25-35.

UNDERWOOD, G., 1967. A contribution to the classification of snakes. British Museum (Natural History), London.

URBANI, J.-M. \& V.L. BELS, 1995. Feeding behaviour in two scleroglossan lizards: Lacerta viridis (Lacertidae) and Zonosaurus laticaudatus (Cordylidae). J. Zool. (Lond) 236: 265290.

WAINWRight, P.C., D.M. KRAKLAU \& A. F. BENNETT, 1991. Kinematics of tongue projection in Chamaeleo oustaleti. J. Exp. Biol. 159: 109-133.

WAINWRIGHT, P.C. \& A.F. BENNETT, 1992. The mechanism of tongue projection in chameleons. I. Electromyographic tests of functional hypotheses. J. Exp. Biol. 168: 1-21.

WAINWRIGHT, P.C. \& A.F. BENNETT, 1992. The mechanism of tongue projection in chameleons. II. Role of shape change in a muscular hydrostat. J. Exp. Biol. 168: 23-40.

WALLS, G., 1942. The vertebrate eye and its adaptive radiation. Hafner, New York.

YounG, B.A., 1988. The arthrology of the head of the red-sided garter snake, Thamnophis sirtalis parietalis. Neth. J. Zool. 38: 166-205. 


\section{APPENDIX}

Reported species with akinetic skulls, and in kinetic skulls the sites of movement within lizard species. $\mathrm{P}=$ Preserved, $\mathrm{OB}=\mathrm{Observed}$ (declaration w/out other experiments), $\mathrm{L}=$ Live, $\mathrm{CF}=$ Cineflourography, $\mathrm{C}=$ Cine, $\mathrm{CR}=$ Cineradiography, $\mathrm{PH}=\mathrm{Photographs} \mathrm{SG}=\mathrm{Strain}$ gauge, $\mathrm{NA}=$ Not available.

\begin{tabular}{|c|c|c|c|c|c|c|c|}
\hline Lizard & akinetic & metakinetic & mesokinetic & prokinetic & streptostyly & method & source \\
\hline \multicolumn{8}{|l|}{$\overline{\text { GEKKONIDAE }}$} \\
\hline Tarentola mauritannica & & $\mathrm{x}$ & $\mathrm{x}$ & & $\mathrm{x}$ & $\mathrm{P} / \mathrm{OB}$ & Frazzetta, 1962 \\
\hline Gecko gecko & & & $\mathrm{x}$ & & $\mathrm{x}$ & NA & DeVree \& Gans, 1987a \\
\hline \multicolumn{8}{|l|}{ AGAMIDAE } \\
\hline Agama caucasica & $\mathrm{x}$ & & & & & $\mathrm{OB}$ & Iordansky, 1966 \\
\hline Uromastix acanthinurus & & $\mathrm{x}$ & $\mathrm{x}$ & & & $\mathrm{P} / \mathrm{OB}$ & Frazzetta, 1962 \\
\hline Uromastix aegyptius & $\mathrm{x}$ & & & & $\mathrm{x}$ & $\mathrm{C}$ & Throckmorton, 1976 \\
\hline Amphibolurus barbatus & $\mathrm{x}$ & & & & $\mathrm{x}$ & $\mathrm{C} / \mathrm{CF}$ & Thromorton \& Clarke, 1981 \\
\hline Cyclura macleayi & $\mathrm{x}$ & & & & $\mathrm{x}$ & $\mathrm{OB}$ & Iordansky, 1987 \\
\hline \multicolumn{8}{|l|}{ CHAMELEONTIDAE } \\
\hline Chamaelo oweni & $\mathrm{x}$ & & & & $\mathrm{x}$ & $\mathrm{P} / \mathrm{OB}$ & Frazzetta, 1962 \\
\hline \multicolumn{8}{|l|}{ IGUANIDAE } \\
\hline Lophosaura ventralis & $\mathrm{x}$ & & & & $\mathrm{x}$ & $\mathrm{P} / \mathrm{OB}$ & Brock, 1938 \\
\hline Crotaphytus wisliszeni & & $\mathrm{x}$ & $\mathrm{x}$ & & & $\mathrm{P} / \mathrm{OB}$ & Frazzetta, 1962 \\
\hline Ctenosaura pectinata & & $\mathrm{x}$ & $\mathrm{x}$ & & & $\mathrm{P} / \mathrm{OB}$ & Frazzetta, 1962 \\
\hline Ctenosaura similis & & $\mathrm{x}$ & $\mathrm{x}$ & & & $\mathrm{P} / \mathrm{OB}$ & Frazzetta, 1962 \\
\hline Phrynosoma solare & & $\mathrm{x}$ & & & & $\mathrm{P} / \mathrm{OB}$ & Frazzetta, 1962 \\
\hline Scleroporous occidentalis & & $\mathrm{x}$ & $\mathrm{x}$ & & & $\mathrm{P} / \mathrm{OB}$ & Frazzetta, 1962 \\
\hline Uta stansburiana & & $\mathrm{x}$ & $\mathrm{x}$ & & & $\mathrm{P} / \mathrm{OB}$ & Frazzetra, 1962 \\
\hline Ctenosaura? & & & & & $\mathrm{x}$ & $\mathrm{CR}$ & Smith, 1978 \\
\hline
\end{tabular}


APPENDIX

\begin{tabular}{|c|c|c|c|c|c|c|}
\hline Lizard & akinetic & metakinetic & mesokinetic prokinetic & streptostyly & method & source \\
\hline \multicolumn{7}{|l|}{$\overline{\text { SCINCIDAE }}$} \\
\hline Tiliqua scincoides & & $\mathrm{x}$ & $\mathrm{x}$ & & $\mathrm{P} / \mathrm{OB}$ & Frazzetta, 1962 \\
\hline Trachydosaurus rugosus & $\mathrm{x}$ & & & $\mathrm{x}$ & $\mathrm{CF} / \mathrm{OB}$ & Gans et al., 1985 \\
\hline Eumeces schneideri & & $\mathrm{x}$ & $\mathrm{x}$ & $\mathrm{x}$ & $\mathrm{OB}$ & Iordansky, 1990 \\
\hline \multicolumn{7}{|l|}{ TEIIDAE } \\
\hline Cnemidophorous tesselatus & & $\mathrm{x}$ & $\mathrm{x}$ & & $\mathrm{P} / \mathrm{OB}$ & Frazzetta, 1962 \\
\hline Tupinambis nigropunctatus & & $\mathrm{x}$ & $\mathrm{x}$ & & $\mathrm{P} / \mathrm{OB}$ & Frazzetta, 1962 \\
\hline Tupinambis teguixin & & $\mathrm{x}$ & $\mathrm{x}$ & & $\mathrm{P} / \mathrm{OB}$ & Frazzetta, 1962 \\
\hline Tupinambis nigropunctatus & & & & $\mathrm{x}$ & $\mathrm{CF}$ & Smith, 1980 \\
\hline \multicolumn{7}{|l|}{ LACERTIDAE } \\
\hline Lacerta agilis & & $\mathrm{x}$ & & & OB & Iordansky, 1966 \\
\hline Lacerta agilis & & $\mathrm{x}$ & $\mathrm{x}$ & & $\mathrm{P} / \mathrm{OB}$ & Frazzetta, 1962 \\
\hline Lacerta muralis & & $\mathrm{x}$ & $\mathrm{x}$ & & $\mathrm{P} / \mathrm{OB}$ & Frazzetta, 1962 \\
\hline Lacerta viridis & & $\mathrm{x}$ & $\mathrm{x}$ & & $\mathrm{P} / \mathrm{OB}$ & Frazzetta, 1962 \\
\hline \multicolumn{7}{|l|}{ AMPHISBAENIDAE } \\
\hline Amphisbaena alba & & & $x(?)$ & & $\mathrm{P} / \mathrm{OB}$ & Frazzetta, 1962 \\
\hline Amphisbaena fuliginosa & & & $x(?)$ & & $\mathrm{P} / \mathrm{OB}$ & Frazzetta, 1962 \\
\hline \multicolumn{7}{|l|}{ ANGUIDAE } \\
\hline Anguis fragilis & & $\mathrm{x}$ & & & $\mathrm{P} / \mathrm{OB}$ & Bellairs, 1950 \\
\hline Anguis fragilis & & $\mathrm{x}$ & $\mathrm{x}$ & & $\mathrm{P} / \mathrm{OB}$ & Frazzetta, 1962 \\
\hline Gerrhonotus coeruleus & & $\mathrm{x}$ & $\mathrm{x}$ & & $\mathrm{L}: \mathrm{C} / \mathrm{L} / \mathrm{OB}$ & Frazzetta, 1962 \\
\hline Gerrhonotus multicarinaus & & $\mathrm{x}$ & $\mathrm{x}$ & $\mathrm{x}$ & $\mathrm{CL}: \mathrm{C} / \mathrm{L} / \mathrm{OB}$ & Frazzetta, 1981 \\
\hline
\end{tabular}


APPENDIX

(Continued)

\begin{tabular}{|c|c|c|c|c|c|c|c|}
\hline Lizard & akinetic & metakinetic & mesokinetic & prokinetic & streptostyly & method & source \\
\hline \multicolumn{8}{|l|}{ ANNIELLIDAE } \\
\hline Anniella pulchra & & & $\mathrm{x}$ & & & $\mathrm{P} / \mathrm{OB}$ & Frazzetta, 1962 \\
\hline Anniella pulchra & & & $\mathrm{x}$ & & & $\mathrm{P} / \mathrm{OB}$ & Bellairs, 1950 \\
\hline \multicolumn{8}{|l|}{ HELODERMATIDAE } \\
\hline Heloderma suspectum & & $\mathrm{x}$ & $\mathrm{x}$ & & & $\mathrm{P} / \mathrm{OB}$ & Frazzetta, 1962 \\
\hline \multicolumn{8}{|l|}{ VARANIDAE } \\
\hline Varanus indicus & & $\mathrm{x}$ & $\mathrm{x}$ & & & $\mathrm{P} / \mathrm{L} / \mathrm{OB}$ & Frazzetta, 1962 \\
\hline Varanus salvator & & $\mathrm{x}$ & $\mathrm{x}$ & & & $\mathrm{P} / \mathrm{L} / \mathrm{OB}$ & Frazzetta, 1962 \\
\hline Varanus varius & & $\mathrm{x}$ & $\mathrm{x}$ & & & $\mathrm{P} / \mathrm{L} / \mathrm{OB}$ & Frazzetta, 1962 \\
\hline Varanus dumerilli & & & & & $\mathrm{x}$ & PH & Krebs, 1979 \\
\hline Varanus bengalensis & & & & & $\mathrm{x}$ & $\mathrm{CF}$ & Rieppel, 1978 \\
\hline Varanus niloticus & & & $\mathrm{x}$ & & & $\mathrm{C}$ & Boltt \& Ewer, 1964 \\
\hline Varanus? & & & & & $\mathrm{x}$ & $\mathrm{CR}$ & Smith, 1978 \\
\hline \multirow[t]{2}{*}{ Varanus exanthematicus } & & & & & $\mathrm{x}$ & $\mathrm{CR}$ & Smith, 1982 \\
\hline & & & & & & SG & Smith \& Hylander, 1985 \\
\hline Varanus niloticus & & & $\mathrm{x}$ & & & $\mathrm{C}$ & Condon, 1987 \\
\hline \multicolumn{8}{|l|}{ PYGOPODIDAE } \\
\hline Lialis butonis & & & $\mathrm{x}$ & & $\mathrm{x}$ & $\mathrm{L} / \mathrm{OB}$ & Patchell \& Shine, 1986 \\
\hline Pygopus lepidopodus & & & $\mathrm{x}$ & & & $\mathrm{L} / \mathrm{OB}$ & Patchell \& Shine, 1986 \\
\hline Delma inornata & & & $\mathrm{x}$ & & & $\mathrm{L} / \mathrm{OB}$ & Patchell \& Shine, 1986 \\
\hline Delama fraseri & & & $\mathrm{x}$ & & & $\mathrm{L} / \mathrm{OB}$ & Patchell \& Shine, 1986 \\
\hline
\end{tabular}


